\title{
The Specificities of the Relationship of the Comparative and the Historical Methods in the Research of Political History
}

\author{
Dragan Tancic \\ Institute of Serbian Culture Leposavic, Serbia \\ Dalibor Elezovic \\ The University of Mitrovica, \\ Faculty of Philosophy, Serbia \\ Miodrag Gordić \\ The University "Union - Nikola Tesla”, Serbia
}

Doi: $10.2478 / \mathrm{mjss}-2018-0025$

\begin{abstract}
This paper discusses the issue of the specificities of the relationship of the comparative and the historical methods in the research of political history. We find examples of the relationship of the comparative and the historical methods in the research of political history in works of modern historiography. Contemporary political history studies various forms of political reality, a variety of themes and those subject to fad, like other branches of history. The analysis has shown that all general scientific methods, particularly the historical method, as well as the comparative method, enable the scientific cognition of social, historical and political phenomena and processes, which also applies to the research of political history.
\end{abstract}

Keywords: methodology, political history, comparative method, historical method

\section{Introduction}

Political history is one of scientific disciplines of political science and historical science, whose object of study is the political history of nations and states, political institutions and their forms, where various political decisions were made and implemented, which were of different forms and content, of different intensity and direction, which had positive or negative political results, effects and consequences for one or more of nations and their states. Political decision-making covers areas of internal and foreign policy. The objects of research of political history are, among other things, the formation and development of political institutions, political and state authorities, political behaviors of holders of political and state functions, leaders and those who are led, various forms of communication and political culture, and the like. Politics, political institutions, states, state organizations, political power and political force are not timeless phenomena, but historically variable phenomena, structures and processes. Thus, since the creation of the state, since Antiquity, the Middle Ages, politics and political power have been changing by permanent condensing and complexification of institutional decision-making and the apparatus of power, and in this way, the contents of political communication and the forms of practicing political power and force have been changing, as well (Tosh, 2008). In contemporary understanding, methodology as a 
separate scientific discipline is seen in the historical community in two diametrically opposed ways. A number of historians absolutely refuse to follow a particular methodology and methodological knowledge and refuse to apply them, while others follow and implement methodological knowledge. Objections to the methodological knowledge of historians in contemporary conditions occur due to the specificities of the development of the historiographical guild and the attitude of researchers in the process of gaining scientific knowledge. At the turn of the millennium, historians have shown that they want to change the status of history as a science, and emphasize its importance for historical knowledge in society and the formation of historical consciousness (Kozodoy, 2009).

\section{Method}

When it comes to the methodological aspect of our paper, we adhere to an established practice in the methodology of social and political sciences, where classification criteria based on generality and adequacy of the method, usability and affiliation with the research subject are usually present. We have strived to make our research about the relationship of historical and comparative methods consistent with the practice, according to which, scientific research has a determined structure and procedure, defined criteria of selection and evaluation, and norms of practice. In order to contribute to the development of science and scientific knowledge, which implies a permanent process and a functional, very complex, logical, productive system of compliant parts and factors that lead to scientific knowledge, our research has taken into consideration a critical study of the results of previous research and, after appropriate evaluation and selection, relied on already gained scientific research knowledge. We were guided by the criteria of data collecting, sorting and processing, as well as the criteria of drawing conclusions from the collected data. We applied general scientific methods used in the research of all kinds of phenomena, i.e. the basic methods: analysis and synthesis, induction and deduction. In accordance with the scientific topic being researched, the use of the comparative method was unavoidable, since essentially, general comparison objects are all social phenomena, those in which one can identify a certain quality, in our case, between which there is a degree of possibility to determine the sameness and similarities.

\section{Results and Discussion}

When it comes to the relationship between the comparative and the historical methods in the study of political history, we immediately have to point out the fact that examples of the application of the comparative analysis and the comparative method can be found in many works of modern history. In this context, we will mention J. Bodin, J. Locke, Montesquieu, J. J. Rousseau, J. S. Mill, H. Spencer, A. Comte, G. W. F. Hegel, then K. Marx, Emile Durkheim and others. It can be noted that the comparative historical approach is an integral part of Max Weber's theoretical and methodological comprehension. His ideal types method is a result of his long and systematic research of social phenomena on a comparative basis (Jordan, 2009). Weber points out to significant possibilities, as well as limitations of the comparative approach in the following deliberations: "The abstract and theoretical method is even today in the immediate and seemingly insurmountable asperity against the empirical and historical research. It correctly recognizes the methodological impossibility of replacing the historical knowledge of reality with formulating a "law" or vice versa, to arrive to the "law" in the strict sense of the word by means of mere comparative historical observations" (Gordic, Termiz, Tancic, 2015). In his papers, Émile Durkheim emphasized the special importance of the comparative method in the study of all the societies on which data existed. He was a researcher who derived new knowledge from the sphere of experience, and it can be said that he was a consistent inductivist. In his early years of practicing science and scientific research, his faith in high cognitive ability of the comparative method and comparative sociology was characteristic of him, and, for him, it was a substitute for the experiment. In this glorification of the comparative method in the early years of development, he claimed that "comparative sociology is not a special branch of sociology, but it is sociology itself if it ceases to be clear and descriptive and seeks to understand the facts" (Gordic, Termiz, Tancic, 2015). Durkheim often linked the comparative analysis method with historical studies of society and emphasized the advantages of this link, because he believed that history, in the study 
of social reality, should have the role of the microscope in the study of the physical world. According to Durkheim, only history can reveal the series of causes and effects from which the current system of education stems (Breisach, 2009).

It is known that political history studies various forms of political reality, therefore, its topics are diverse and subject to fashion, as well as in other branches of history. Since the $19^{\text {th }}$ century, in historiography, the term political history has implied the research of political processes at the level of state bodies and decision-makers. The practice of traditional historiography to limit its field of research to actions of states, nations and their governments, and to equate them, at the same time, with general history stems from the life experience of $19^{\text {th }}$-century historians. They were under the impression of the creation of a modern state as an instrument of providing internal peace, and, partially, they directly experienced the rise of the modern nation state and the state as power. Their writing of history was part of the national pedagogical task. This experience was especially expressed in Germany, as a "belated" nation (Tosh, 2008).

As a common, general feature in the application of the comparative method in a majority of authors, the following can be pointed out: the comparative method has been applied by various scientists in the study of various phenomena and diverse content by keeping in mind the course of the historical development of the society or has studied social, political, economic, legal phenomena and activities, such as the family, property, religion, art, customs and the like. In the early $19^{\text {th }}$ century, the comparative method was associated with evolutionist ideas and was used for collecting and sorting the experiential material on the society, in order to express different views on the development of the society. During this period, comparative studies were carried out in cabinets to a greater extent, using numerous of the available data sources (different attitudes of travelers, missionaries and the like), while critique of sources and their verification, i.e. the examination of their completeness and reliability, were not present sufficiently. According to American authors D.P. Warwick and Samuel Osherson, the comparative method is "in short, we use the term comparative method in order to imply social scientific analyses, which involve observation in more than one social system or in the same social system at more than one point in time. We emphasize that our definition is not associated with any specific research methodology. Comparisons between societies, experimenting in small groups, using aggregate data, participating observation, content analysis, or any selection from a wide repertoire of social science methods" (Gordic, Termiz, Tancic, 2015).

Medeloine Grawitz does not provide a complete definition of the comparative method, but she does discuss its basic features, stating that the comparative method has no special technical procedure; that it is applied in all social sciences; that it can be equally used in all stages of the research; that it is particularly important during the conceptualization of the research process; that it has its place on all levels of research.

The application of the comparative method in the Serbian science is associated with Valtazar Bogisic, Jovan Cvijic, A. Radic, Vojin Milic, Radomir Lukic, Mihailo Markovic, Miroslav Pecujlic, Ilija Stanojcic, Mihailo Djuric, Bogdan Sesic, Slavomir Milosavljevic, Ivan Radosavljevic and other authors (Milosavljevic, 1980).

Vojin Milic expressed his viewpoint of the comparative method in an article published in 1958, at a time when Serbian research fund in the field of comparative studies was very small. According to Vojin Milic, the comparative method is an integral part of the sociological method, and he points out that any comparison of social phenomena cannot be labeled as the comparative method. According to the same author, "the comparative method can be defined as an effort to study particular types of social phenomena or the society in their more complex forms, to study them in all their forms or at least in as numerous and as different forms as possible, and those forms result from different socio-historical and natural conditions" (Milic, 1958).

Then, in the example of comparative studies of the family, he states the essential constituents of this definition of the comparative method. Namely, in the comparative study of the family, attempts are made to explore all the different forms in which the family appears in the development of the society and to discover why, i.e. on what kind of general social conditions the occurrence of some of its forms depend. Based on this, he concludes that these attempts aim to explore the full experiential range of qualitative and quantitative degrees of some kind of phenomena, not general 
mental operations. Milic, bearing in mind the above mentioned understanding of the comparative method, states two main groups of tasks of this method. The first group is focused on describing systematically the various forms of global societies and certain types of social phenomena, and the second group of tasks is focused on explaining these societies and certain types of social phenomena. In addition, Milic points out that general conclusions about any type of social phenomenon cannot be drawn and systematically verified if we are not familiar with all its experiential qualitative forms, and all its sizes and intensities. "The historicity of social phenomena requires careful monitoring in order to see if the phenomenon will appear in a new historical situation in its new form and with new distinctive relationships with other social phenomena. Still unknown forms of phenomena and their relationships with other phenomena may, certainly, be discovered in the past, as well. Without a systematic descriptive base, all generalizations must remain unmethodical" (Milic, 1996). Vojin Milic's point of view, in which he emphasizes that the true value of the comparative method does not manifest itself in the description, but during the explanation of the established relationships between phenomena in order to detect their general conditions and causes, as well as specific causes as a result of which a phenomenon occurs in its particular qualitative forms and different intensities, is important, since "the scientific explanation is based on the discovery of deterministic relationships between phenomena, primarily those relationships for which there are sufficient reasons to be assumed that their nature is causal." This is mainly the base for his conclusion that: the more one of these relationships can be examined in multiple, concrete, historical situations and proved that the relationship is always established, the more the hypothesis that a more general social law comes to the fore in it becomes justified (Gordic, Termiz, Tancic, 2015).

In the second edition of his book "The Sociological Method" in 1978, Milic expresses his point of view in relation to Marx's point of view regarding the comparative-historical approach, stating that this approach was included in Marx's methodological point of view, although Marx did not elaborate or apply it in a wider way.

Bogdan Sesic points out that the methodological approach to comparing is one of the basic methodological procedures of human cognition and that it is a more fundamental cognitive procedure than generalization and induction, which, in the $19^{\text {th }}$ century, transformed in a general method of linguistic, literary and anthropological research. The author stresses that the comparative method had a significant role not only in the social sciences, but also in mathematics and natural sciences, astronomy, physics, geography and biology, and it is undisputed that the comparative method is one of the general methods of scientific research. The object of study of the comparative research method is related or similar phenomena of different types of the same genus of the phenomenon, any natural or social phenomena. An essential requirement for the application possibility of the comparative method is the existence of identical or at least similar, analogous properties in multiple types of phenomena. However, the basic subjective requirement for the possibility of applying the comparative method is a cognitive-mental-theoretical and a practical possibility of cognition or a discovery of analogous structures, processes and behaviors in multiple non-identical, i.e. different phenomena (Sesic, 1971).

The comparative method can also be applied in the study of different genera, i.e. completely different kinds, but - as noted by the author - in this case, the results of the comparative method are not as prolific as in the first case, i.e. in the comparison of phenomena of two or more kinds of the same genus. Direct objects of study by means of the comparative method are connections and relationships of similarities and dissimilarities between at least two kinds of phenomena of a genus of phenomena. Hence, these similarities and dissimilarities can pertain a wide variety of properties of the phenomena being researched, namely: content, forms, quality, dimensions, structures, functions, methods of creation, changes and developments, as well as ways of actions and behaviors, i.e. people's activities. Objects of study of the comparative method are also relationships and connections, structures, functions and behaviors of at least two phenomena or two kinds of phenomena, or classes or groups of people or types of social organizations.

Mihailo Djuric attaches special importance to the historical study of society and social phenomena, where he emphasizes that the comparative method is an indispensable analytical tool in discovering social laws. His considerations of logical and technical problems of the comparative 
approach are largely similar to Milic's treatment of these problems. He, just like Milic, emphasizes the role and importance of the comparative method as a substitute for the experiment. He points out, just like Milic, that the comparative method has the highest value in verifying hypotheses and theories of a higher level of generality. Mihailo Djuric emphasizes that the comparative historical method can be applied in many different ways, depending on whether the research remains at the national level of a social organization or expands to a broader international level (Djuric, 1971). In this context, Karabuscenko accentuates that political history attempts to provide an objective assessment of the activities and decisions of the political elite and its leaders. The problem is that often the research cannot be implemented because of the resistance of the very elites, who do not want to be open to elitological research (Karabuscenko, 2013).

When discussing the comparative method, Slavomir Milosavljevic and Ivan Radosavljevic point out that it is called comparative, historical-comparative and the like. Differences in the names have their basis in determining the comparative method. They emphasize the importance of comparison and point out that the comparison is a factor in the process of thinking and cognition, that it is a cognition method (Milosavljevic, Radosavljevic, 2013).

A great controversy has existed regarding the question of whether it is possible to analyze the field of international relations by means of social methods. However, as before, they tend to interpret foreign policy, primarily as a result of major social conflicts in the bosom of individual societies and not to treat it as separated from international relations in the form of diplomatic skills. History of foreign policy and international relations is, thus, still necessary social and cultural history, which cannot be confined to relationships with national contexts and the creation of national states. However, especially in the $19^{\text {th }}$ and the $20^{\text {th }}$ centuries, another, more complex interdependence was developed, so domestic policy has increasingly become internationalized, while foreign policy has increasingly been placed into the social and the domestic policy context (Van Dilmen, 2010).

On the other hand, more complex issues arise when one tries to determine the comparative method as a scientific, research method. In this context, researchers raise the question of whether this is a method or whether it can be reduced to a methodical process, and second, if it is a method, on the basis of what it can be considered as a method, and third, what kind of a method it is and what its relationship with comparative research is. Interpreters of this question (referring to Nagel's understanding) point out that it is wrong to treat the comparative method only as a method of history and reject its possibilities in detecting the existence of the sameness, differences and similarities in content and forms of life of a society in a given period. They also emphasize that it is incorrect to consider this method as finished and disqualify it because it does not explain the earliest beginnings of the human society and its development. In addition, they point out that the comparative method is not applied only in comparative research, but in all kinds of research. The use of the comparative method in political science is especially highlighted, in particular, whether this method is possible in political science, what its subject is, what and how to compare, on what kind of data - on what kind of records the comparison should be based, and the like, where several basic approaches include diffusionism, the concept of the correlation analysis, comparative studies such as area studies, and comparative research oriented to differentiating classifications and typologies. All the approaches to the comparative method and comparative studies point out several essential questions, such as: what is comparable, what can be identified as a policy and as an object of comparison. Bearing in mind the general, standard object of study of politicology, the authors emphasize that each segmented and elemental factor contained in it can be compared in the same way that wholes, which are understood (determined) as a process, a system, and as a structural-functional entity, can be compared. The comparative method is applied like other methods, in accordance with the regulations of the research project. They particularly point out its dependence on sources of data, systematized, sufficient and valid data of experiential origin and personal insights of researchers into the research environment. The comparative analysis has tasks to describe, classify, typologize, create and enrich definitions, generalizations, determine the causeeffect correlation, to predict, and the characteristics of experimental methods, i.e. a quasiexperiment by the name of "natural experiment," are rightfully attributed to it (Gordic, Termiz, Tancic, 2015). 


\section{Conclusion}

We conclude that all general scientific methods, especially the historical method, as well as the comparative method, enable scientific understanding of social, historical and political phenomena and processes, and research on political history. Why do we particularly emphasize the historical method and the comparative method? In our view, the historical method and the comparative method have a higher degree of applicability and pervasiveness in all sciences and scientific disciplines in relation to other general scientific methods, taking into account their general and basic properties, which we have presented in this paper. Namely, it is indisputable that all phenomena, regardless of whether they are natural, social, political, legal, sociological or other phenomena, have their own stages and phases of formation, development and disappearance, which can be expressed as a general agreement in a majority of authors who have discussed these two general scientific methods. In other words, there are no permanent, eternal forms of natural, social, political and other phenomena, state, national, political and other creations, bodies and structures, but, everything that existed had been developing and changing, and it also disappeared. Examples of this are various states, their emergence, development and disappearance, both in the distant and in the recent past.

\section{References}

Blek, Dž. Mekrejld, D. (2007): Izučavanje istorije. Beograd: Clio.

Brajzah, E. (2009): Istoriografija. Beograd: Clio.

Deletić, Z. (2017): Metodologija istraživanja istorije. Podgorica: Crnogorska akademija nauka i umjetnosti.

Elezovic D. (2014): Seifert's explication of historicism and the subject of research of historical science. European science review, 9-10, 16-19.

Gordic, M. Termiz, Dz. Tancic, D. (2015): Metodoloski osnovi istrazivanja bezbednosti, odbrane i terorizma. Leposavic: Institut za srpsku kulturu.

Gross, M. (2001): Suvremena historiografija: korijeni, postignuća, traganja. Zagreb: Novi liber.

Đurić, M. (1971): Istorija političke filozofije. Beograd: Savez studenata Pravnog fakulteta.

Jordan, S. (2009): Theorien und Methoden der Geschichtswissenschaft. Paderborn: Ferdinand Schöningh.

Karabushchenko P. (2013): Politicheskaya nauka i problemyi falsifikatsii politicheskoy istorii. Vestnik Volgogradskogo Gosudarstvenogo universiteta. 1, 23, 96-102.

Kozodoy V. (2005): Problemyi metodologii politicheskoy istorii. Interekspo Geo-Sibir, 1, 1-4.

Lukić, R. (1970): Osnovi sociologije. Beograd: Naučna knjiga.

Marković, M. (1961): Opšta metodologija naučnog istraživanja. Beograd: Udruženje studenata sociologije.

Milić, V. (1958): Komparativni metod u sociologiji. Filozofija-Sociologija, 1-2, 48-66.

Milić, V. (1996): Sociološki metod. Beograd: Zavod za udžbenike i nastavna sredstva.

Milosavljević, S. (1980): Istraživanje političkih pojava. Beograd: Institut za političke studije.

Milosavljević, S. Radosavljević, I. (2013): Osnovi metodologije političkih nauka. Beograd: Službeni glasnik.

Pečujlić, M. Milić, V. (1994): Uvod u metodologiju društvenih nauka. Beograd: Univerzitet Braća Karić.

Sal, V. (2008): Istoričari. Beograd: Clio.

Šešić, B. (1971): Opšta metodologija. Beograd: Naučna knjiga.

Toš, Dž. (2008): U traganju za istorijom. Beograd: Clio.

Tančić D. (2012): Osnove istorijskog metoda. Leposavic: Institut za srpsku kulturu.

Van Dilmen, R. (2010): Istorija. leksikon pojmova. Beograd: Clio. 